MTR 01312

\title{
Mutagenicity of aromatic glycidyl ethers with Salmonella
}

\author{
L.B. Rosman, P.K. Chakraborty, E.A. Messerly and J.E. Sinsheimer \\ College of Pharmacy, University of Michigan, Ann Arbor, MI 48109-1065 (U.S.A.)
}

(Received 23 November 1987)

(Revision received 16 February 1988)

(Accepted 23 February 1988)

Keywords: Glycidyl ethers, aromatic; Ames test; Phenyl glycidyl ethers; 4-(4-Nitrobenzyl) pyridine

\section{Summary}

6 aromatic glycidyl ethers containing naphthyl, biphenyl or benzylphenyl substituents were synthesized. These epoxides together with the commercially available compounds 2-biphenylyl glycidyl ether were examined for dose-mutagenicity relationships using the plate incorporation Ames test with Salmonella typhimurium strains TA100 and TA1535. Structure-mutagenicity relationships were further examined for these compounds and 3 phenyl glycidyl ethers by concurrent testing at a single dose with strain TA100. Meaningful correlations could not be established for the mutagenicity of these epoxides to their molecular volumes, partition values, nor to their reactivities with the model nucleophile, 4-(4-nitrobenzyl) pyridine. However, it was noted that increased conjugated aromatic unsaturation with its resulting planarity led to increased mutagenicity and that this effect decreased when it was further removed from the epoxide moiety.

Mono- and di-functional glycidyl ethers are employed in epoxy-resin systems and to improve the processing and stability of materials in the polymer industry. A battery of in vitro (Nishioka and Ohtani, 1978; Greene et al., 1979; Wade et al., 1979; Connor et al., 1980; Hemminki et al., 1980; Thompson et al., 1981; Voogd et al., 1981; Frost and Legator, 1982; Sugiura and Goto, 1983; Seiler, 1984a) and in vivo (Terrill and Lee, 1977; Greene et al., 1979; Terrill et al., 1982; Whorton et al., 1983; Seiler, 1984a, b) experiments assessed the genotoxic potential of these chemicals. Hopkins (1984) reviewed their status as animal carcinogens as well as occupational hazards and

Correspondence: Dr. J.E. Sinsheimer, College of Pharmacy, University of Michigan, Ann Arbor, MI 48109-1065 (U.S.A.). concluded that although these compounds are mutagenic in vitro, in vivo studies need more emphasis. Workers exposed to glycidyl ethers primarily suffer skin and eye irritation and allergic reactions. High doses may lead to systemic toxicity (NIOSH, 1978; Stein et al., 1979; Fishbein, 1981). Stein et al. (1979) warned of potentially adverse testicular and hemopoietic effects from worker exposure.

Research on these compounds extends our structure-activity work on aliphatic and aryl epoxides (Wade et al., 1978; Frantz and Sinsheimer, 1981; Neau et al., 1982; Frantz et al., 1985; Rosman et al., 1986, 1987). Our studies on monosubstituted aliphatic epoxides (Wade et al., 1978) and cyclohexane oxiranes (Frantz et al., 1985 ) indicated a relationship between mutagenicity and electrophilicity. In Neau et al. (1982), we 
demonstrated a strong positive correlation between Hammett constants and the mutagenicity of several glycidyl ethers. Electrophilicity was also correlated to mutagenicity of unsubstituted and substituted styrene oxides (Sugiura et al., 1978a, b; Sugiura and Goto, 1981). Tamura et al. (1982)

\section{TABLE 1}

\section{STRUCTURES OF THE TEST COMPOUNDS}

\begin{tabular}{lll}
\hline Glycidyl ethers & Structure & Salmonella assay references \\
\hline Phenyl & Nishioka and Ohtani (1978); Greene \\
& et al. (1979); Hemminki et al. \\
& $(1980)$; Ivie et al. (1980); \\
Neau et al. (1982); Seiler & $(1984 a) ;$ Canter et al. (1986)
\end{tabular}

$4-N$ itrophenyl

4-Methoxypheny!

2-Biphenylyl

4-Biphenylyl

2-Eenzy'pheny'

$4-$ Benzylpneryl

1-Naphthyl

$2-$ Naphthyl
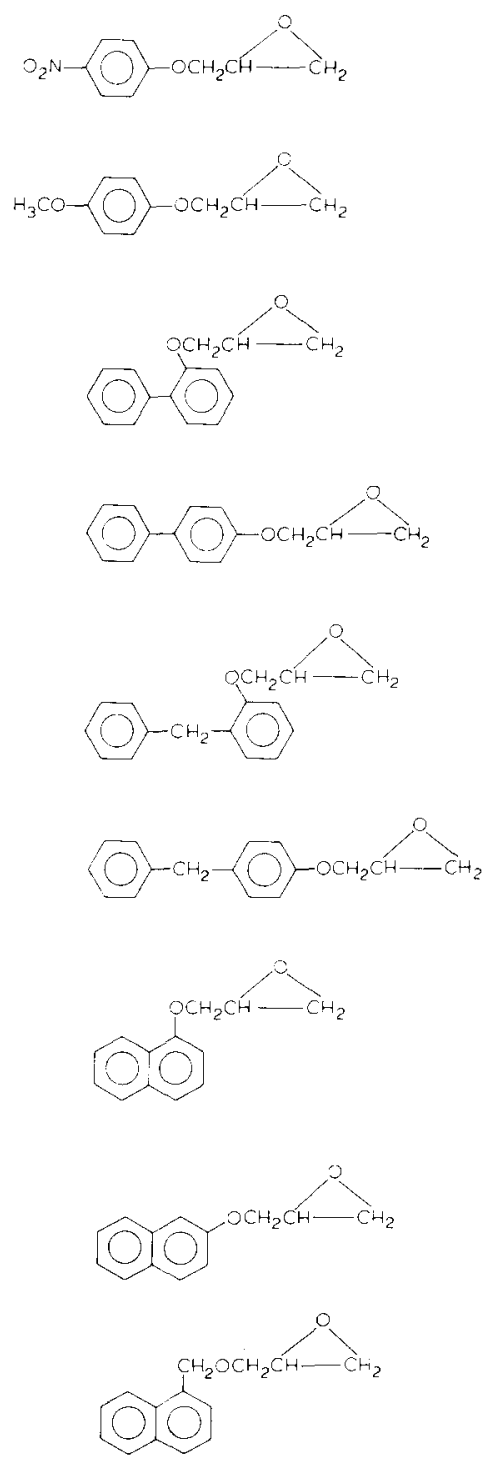

Neau et al. (1982)

Neau et al. (1982) 
and Rosman et al. (1986) showed that molecular volume and hydrophobicity as well as electrophilicity were good indicators of mutagenicity for styrene oxides and $\alpha$-methylstyrene oxides, respectively.

Conversely, we observed (Rosman et al., 1987) that the classical structure-activity parameters were not good predictors of aryloxide mutagenicity but an increase in mutagenicity of compounds containing conjugated aromatic unsaturation was noted. The number of aromatic rings and the distance of the oxirane structure from the aromatic group was also a factor in the study of Sugiura and Goto (1983) on glycidyl ethers.

The structures of the epoxides investigated in the present study are listed in Table 1 . We have synthesized 6 glycidyl ethers containing naphthyl, biphenyl or benzylphenyl groups. These epoxides together with the commercially available compound 2-biphenyl glycidyl ether were selected to compare the mutagenicity of a series of glycidyl ethers of similar molecular weights but with differences in the arrangement of their aromatic substituents. One of these compounds, 1-naphthylmethyl glycidyl ether is a known mutagen and is also included together with the established mutagens 4-methoxyphenyl, 4-nitrophenyl and phenyl glycidyl ethers as reference compounds to the previous studies of these and related epoxides (Neau et al., 1982; Sigiura and Goto, 1983). Our objectives were to analyze the physico-chemical properties of molecular size, relative partition values and chemical reactivity for these glycidyl ethers as they relate to mutagenicity as well as examine the effects of conjugated aromatic unsaturation and the degree of separation of the epoxide moiety from the aromatic ring on mutagenicity in the Ames test.

\section{Materials and methods}

\section{Test compounds}

Phenyl glycidyl ether (1,2-epoxy-3-phenoxypropane, 99\%), 2-biphenylyl glycidyl ether (95\%), 4-methoxyphenyl glycidyl ether (2,3epoxypropyl 4-methoxyphenyl ether, 99\%) and the starting materials for the syntheses of the other glycidyl ethers were purchased from Aldrich Chemical Company (Milwaukee, WI). 4-Nitrophe- nyl glycidyl ether was bought from Eastman Kodak Company (Rochester, NY). 1-Naphthylmethyl glycidyl ether was synthesized according to the procedure of Sugiura and Goto (1983). The rest of the compounds were prepared according to the method of Van Zyl et al. (1953) by reacting phenol with epichlorohydrin in dioxane in the presence of sodium hydroxide.

Phenyl glycidyl ether, 4-methoxyphenyl glycidyl ether and 2-biphenylyl glycidyl ether were used without further purification. 4-Nitrophenyl glycidyl ether was purified by repeated recrystallization from ethanol. 1-Naphthyl glycidyl ether and 4-biphenylyl glycidyl ether were chromatographed on silica gel ( $50 \% \mathrm{CH}_{2} \mathrm{Cl}_{2}$-pentane) followed by recrystallization with $\mathrm{CH}_{2} \mathrm{Cl}_{2}$-pentane. The remaining epoxides were purified by distillation under reduced pressure.

\section{Chromatography}

High-performance liquid chromatography (HPLC) was used to determine partition coefficients (Carlson et al., 1975; Sugiura et al., 1978b). The HPLC system consisted of Altex (Berkeley, CA) models 110A pump and 153 fixed-wavelength (254 $\mathrm{nm}$ ) detector, Rheodyne (Berkeley, CA) model 7125 injector $(20 \mu 1)$ and Whatman (Clifton, NJ) Partisil PXS 10/25 ODS-3 column preceded by a guard column $(50 \times 4.6$ I.D.) packed with Whatman Co-Pell ODS $30-38 \mu \mathrm{m}$ pellicular material. The mobile phase was methanol-water $(6: 4)$ at a flow rate of $1 \mathrm{ml} / \mathrm{min}$.

Thin-layer chromatography (TLC) was used to monitor reactions, to determine $R_{\mathrm{f}}$ values and to examine the purity of test compounds. Analtech (Newark, DE) prescored Silica-GF Uniplates (2 $\mathrm{cm} \times 10 \mathrm{~cm}, 250 \mu \mathrm{m}$ ) and $\mathrm{CH}_{2} \mathrm{Cl}_{2}$ as the solvent were employed. A compound was considered suitable for mutagenicity testing when a sample (2 $\mu 1,10 \% \quad \mathrm{CH}_{2} \mathrm{Cl}_{2}$ solution) after development showed only one homogeneous spot under UV observation and after alkylation of 4-(4-nitrobenzyl)pyridine (Hammock et al., 1974).

\section{Alkylating reactions of epoxides}

The alkylating ability of the glycidyl ethers was determined by reaction with 4-(4-nitrobenzyl)pyridine using equimolar concentrations at $37^{\circ} \mathrm{C}$ 
TABLE 2

PROPERTIES OF THE GLYCIDYL ETHERS

\begin{tabular}{|c|c|c|c|c|c|c|c|}
\hline Substituent $^{\text {a }}$ & $\begin{array}{l}\mathrm{MP} \text { or } \\
\mathrm{BP} / \mathrm{mm} \mathrm{Hg}\end{array}$ & $\begin{array}{l}\text { TLC }^{\mathrm{b}} \\
R_{\mathrm{f}}\end{array}$ & $\begin{array}{l}\text { HPLC } \\
T_{\mathrm{R}} \\
(\min : \sec )\end{array}$ & $\pi_{\text {HPLC }} d$ & $\begin{array}{l}V w \\
\left(\AA^{3}\right)^{\mathrm{e}}\end{array}$ & $\begin{array}{l}\text { Nitrobenzyl } \\
\text { pyridine } \\
\text { reaction }\end{array}$ & NMR $\delta{\text { (assignments })^{\mathrm{g}}}^{\mathrm{s}}$ \\
\hline 1. Phenyl & $245^{\circ} \mathrm{C} / 760 \mathrm{~mm}$ & 0.51 & $5: 36$ & 0.000 & 134.2 & $0.273 \pm 0.017$ & $\begin{array}{l}2.80\left(2 \mathrm{H}, \mathrm{dd},-\mathrm{CH}_{\mathrm{a}} H_{\mathrm{b}}\right) \\
3.34(1 \mathrm{H}, \mathrm{m},-\mathrm{C} H-\mathrm{O}) \\
4.05\left(2 \mathrm{H}, \mathrm{dd},-\mathrm{OC} H_{2}\right) \\
6.85(3 \mathrm{H}, \mathrm{m}, \mathrm{Ar}) \\
7.30(2 \mathrm{H}, \mathrm{m}, \mathrm{Ar})\end{array}$ \\
\hline 2. 4-Methoxyphenyl & $48-49^{\circ} \mathrm{C}$ & 0.31 & $5: 30$ & -0.019 & 157.7 & $0.220 \pm 0.007$ & $\begin{array}{l}2.83\left(2 \mathrm{H}, \mathrm{dd},-\mathrm{CH}_{\mathrm{a}} H_{\mathrm{b}}\right) \\
3.33(1 \mathrm{H}, \mathrm{m},-\mathrm{CH}-\mathrm{O}) \\
3.76\left(3 \mathrm{H}, \mathrm{s},-\mathrm{OC} H_{3}\right) \\
4.04\left(2 \mathrm{H}, \mathrm{dd},-\mathrm{OC} H_{2}\right) \\
6.87(4 \mathrm{H}, \mathrm{m}, \mathrm{Ar})\end{array}$ \\
\hline 3. 4-Nitrophenyl & $66-67^{\circ} \mathrm{C}$ & 0.53 & $5: 42$ & 0.018 & 153.0 & $0.254 \pm 0.017$ & $\begin{array}{l}2.86\left(2 \mathrm{H}, \mathrm{dd},-\mathrm{CH}_{\mathrm{a}} H_{\mathrm{b}}\right), \\
3.38(1 \mathrm{H}, \mathrm{m},-\mathrm{CH}-\mathrm{O}), \\
4.21\left(2 \mathrm{H}, \mathrm{dd},-\mathrm{OCH} H_{2}\right) \\
7.00(2 \mathrm{H}, \mathrm{d}, \mathrm{J}=7 \mathrm{~Hz}, \mathrm{Ar}), \\
8.21(2 \mathrm{H}, \mathrm{d}, \mathrm{J}=7 \mathrm{~Hz}, \mathrm{Ar})\end{array}$ \\
\hline 4. 2-Biphenylyl & $30-32^{\circ} \mathrm{C}$ & 0.51 & $13: 00$ & 0.620 & 206.0 & $0.378 \pm 0.034$ & $\begin{array}{l}2.72\left(2 \mathrm{H}, \mathrm{dd},-\mathrm{C} H_{\mathrm{a}} H_{\mathrm{h}}\right) \\
3.25(1 \mathrm{H}, \mathrm{m},-\mathrm{CH}-\mathrm{O}) \\
4.09\left(2 \mathrm{H}, \mathrm{m},-\mathrm{OC} H_{2}\right), \\
7.02(2 \mathrm{H}, \mathrm{m}, \mathrm{Ar}) \\
7.25-7.42(5 \mathrm{H}, \mathrm{m}, \mathrm{Ar}), \\
7.55(2 \mathrm{H}, \mathrm{d}, \mathrm{J}=7 \mathrm{~Hz}, \mathrm{Ar})\end{array}$ \\
\hline 5. 4-Biphenylyl & $92-93^{\circ} \mathrm{C}$ & 0.54 & $16: 00$ & 0.737 & 206.0 & $0.291 \pm 0.023$ & $\begin{array}{l}2.85\left(2 \mathrm{H}, \mathrm{dd},-\mathrm{CH} H_{\mathrm{a}} H_{\mathrm{b}}\right), \\
3.38(1 \mathrm{H}, \mathrm{m},-\mathrm{CH}-\mathrm{O}), \\
4.14\left(2 \mathrm{H}, \mathrm{dd},-\mathrm{OCH} H_{2}\right), \\
7.01(2 \mathrm{H}, \mathrm{d}, \mathrm{J}=8 \mathrm{~Hz}, \mathrm{Ar}), \\
7.24-7.58(7 \mathrm{H}, \mathrm{m}, \mathrm{Ar})\end{array}$ \\
\hline 6. 2-Benzylphenyl & $165^{\circ} \mathrm{C} / 1.2 \mathrm{~mm}$ & 0.58 & $18: 06$ & 0.803 & 220.8 & $0.486 \pm 0.025$ & $\begin{array}{l}2.75\left(2 \mathrm{H}, \mathrm{dd},-\mathrm{CH}_{\mathrm{a}} H_{\mathrm{b}}\right) \\
3.28(1 \mathrm{H}, \mathrm{m},-\mathrm{CH}-\mathrm{O}) \\
\left.\text { 4.00(2H,s,ArC } H_{2} \mathrm{Ar}\right) \\
\text { 4.05(2H,dd,-OCH }) \\
6.80-6.93(2 \mathrm{H}, \mathrm{m}, \mathrm{Ar}) \\
7.08-7.30(7 \mathrm{H}, \mathrm{m}, \mathrm{Ar})\end{array}$ \\
\hline 7. 4-Benzylphenyl & $177-178^{\circ} \mathrm{C} / 1 \mathrm{~mm}$ & 0.49 & $18: 42$ & 0.821 & 220.8 & $0.300 \pm 0.014$ & $\begin{array}{l}2.81\left(2 \mathrm{H}, \mathrm{dd},-\mathrm{C} H_{\mathrm{a}} H_{\mathrm{b}}\right), \\
3.32(1 \mathrm{H}, \mathrm{m},-\mathrm{CH}-\mathrm{O}), \\
3.92\left(2 \mathrm{H}, \mathrm{s},-\mathrm{ArCH} H_{2} \mathrm{Ar}\right), \\
4.08\left(2 \mathrm{H}, \mathrm{dd},-\mathrm{OC} H_{2}\right), \\
6.87(2 \mathrm{H}, \mathrm{d}, \mathrm{J}=7 \mathrm{~Hz}, \mathrm{Ar}), \\
7.08-7.30(7 \mathrm{H}, \mathrm{m}, \mathrm{Ar})\end{array}$ \\
\hline 8. 1-Naphthyl & $165^{\circ} \mathrm{C} / 2 \mathrm{~mm}$ & 0.63 & $11: 48$ & 0.563 & 178.6 & $0.399 \pm 0.015$ & $\begin{array}{l}2.89\left(2 \mathrm{H}, \mathrm{dd},-\mathrm{C} H_{\mathrm{a}} H_{\mathrm{b}}\right), \\
3.48(1 \mathrm{H}, \mathrm{m},-\mathrm{CH}-\mathrm{O}), \\
4.25\left(2 \mathrm{H}, \mathrm{dd},-\mathrm{OC} H_{2}\right), \\
6.80(1 \mathrm{H}, \mathrm{d}, \mathrm{J}=7 \mathrm{~Hz}, \mathrm{Ar}), \\
7.24-7.52(4 \mathrm{H}, \mathrm{m}, \mathrm{Ar}), \\
7.80(1 \mathrm{H}, \mathrm{m}, \mathrm{Ar}), \\
8.30(1 \mathrm{H}, \mathrm{m}, \mathrm{Ar})\end{array}$ \\
\hline
\end{tabular}


TABLE 2 (continued)

\begin{tabular}{|c|c|c|c|c|c|c|c|}
\hline Substituent $^{a}$ & $\begin{array}{l}\mathrm{MP} \text { or } \\
\mathrm{BP} / \mathrm{mm} \mathrm{Hg}\end{array}$ & $\begin{array}{l}\text { TLC }^{\mathrm{b}} \\
R_{\mathrm{f}}\end{array}$ & $\begin{array}{l}\text { HPLC } \\
T_{\mathrm{R}} \\
\text { (min : sec) }^{\mathrm{c}}\end{array}$ & $\pi_{\text {HPLC }}{ }^{d}$ & $\begin{array}{l}V w \\
\left(\AA^{3}\right)^{\mathrm{e}}\end{array}$ & $\begin{array}{l}\text { Nitrobenzyl } \\
\text { pyridine } \\
\text { reaction } f\end{array}$ & NMR $\delta$ (assignments) $^{g}$ \\
\hline 9. 2-Naphthyl & $106-107^{\circ} \mathrm{C}$ & 0.49 & $10: 36$ & 0.497 & 178.6 & $0.372 \pm 0.029$ & $\begin{array}{l}2.90\left(2 \mathrm{H}, \mathrm{dd},-\mathrm{CH} H_{\mathrm{a}} H_{\mathrm{b}}\right) \\
3.43(1 \mathrm{H}, \mathrm{m},-\mathrm{CH}-\mathrm{O}) \\
4.23\left(2 \mathrm{H}, \mathrm{dd},-\mathrm{OC} H_{2}\right), \\
7.21-7.48(4 \mathrm{H}, \mathrm{m}, \mathrm{Ar}) \\
7.75(3 \mathrm{H}, \mathrm{m}, \mathrm{Ar})\end{array}$ \\
\hline 10. 1-Naphthylmethyl & $144^{\circ} \mathrm{C} / 0.7 \mathrm{~mm}$ & 0.27 & $9: 36$ & 0.434 & 194.0 & $0.222 \pm 0.013$ & $\begin{array}{l}2.71\left(2 \mathrm{H}, \mathrm{dd},-\mathrm{CH}_{\mathrm{a}} H_{\mathrm{b}}\right), \\
3.20(1 \mathrm{H}, \mathrm{m},-\mathrm{CH}-\mathrm{O}), \\
3.65\left(2 \mathrm{H}, \mathrm{dd},-\mathrm{OC} H_{2}\right), \\
5.05\left(2 \mathrm{H}, \mathrm{d},-\mathrm{CH} H_{2}-\mathrm{O}\right), \\
7.50(4 \mathrm{H}, \mathrm{m}, \mathrm{Ar}) \\
7.85(2 \mathrm{H}, \mathrm{m}, \mathrm{Ar}) \\
8.25(1 \mathrm{H}, \mathrm{m}, \mathrm{Ar})\end{array}$ \\
\hline
\end{tabular}

a Compounds 1-4 are commercially available. Compounds 5-10 were synthesized by the method of Van Zyl et al. (1953).

b Elution was with $\mathrm{CH}_{2} \mathrm{Cl}_{2}$.

c Retention time $\left(T_{\mathrm{R}}\right)$ includes void time of $3 \mathrm{~min} 16 \mathrm{sec}$.

d ${ }^{\pi}$ HPLC $=\log \left(k^{\prime}\right.$ substituted phenyl glycidyl ether $/ k^{\prime}$ phenyl glycidyl ether $)$. See Carlson et al. (1975).

' van der Waals volumes calculated by the method of Moriguchi et al. (1976).

f Absorbance ( \pm S.D.) at $560 \mathrm{~nm}$ after $40 \mathrm{~min}$ at $37^{\circ} \mathrm{C}$ with $n=6$.

g At $270 \mathrm{MHz}$ in $\mathrm{CDCl}_{3}$.

for $40 \mathrm{~min}$ as described by Hemminki and Falck (1979) and Nelis et al. (1982).

\section{Mutagenicity assays}

Dose-response data for standard plate mutagenicity assays were established for these compounds using the base-pair substitution strains, TA100 and TA1535. These experiments followed the procedures outlined by Maron and Ames (1983) with the specifications previously described for our laboratories (Frantz and Sinsheimer, 1981). The positive control was glycidol (10 $\mu$ moles/ plate) which was checked for normal response for our laboratory. Each compound and dose was tested in triplicate. Dose-response testing was repeated to confirm results.

Single-dose comparisons at $0.25 \mu \mathrm{mole} /$ plate with TA100 were made on the same day using bacteria from the same overnight culture. The number of replicate plates was 3 and results were confirmed in a second experiment.

\section{Results and discussion}

The physico-chemical properties of the glycidyl ethers are listed in Table 2. Molecular volumes
(Moriguchi et al., 1976), partition values and chemical reactivities with nitrobenzylpyridine were determined for possible correlation to mutagenicity. The NMR data are given in confirmation of the structures of these compounds. In this particular series, there is a high correlation $(r=0.941)$ of partition values to molecular volumes. There is relatively little difference in reactivity of these epoxides with nitrobenzyl pyridine as the most reactive compound, the 2-benzylphenyl derivative, is only about twice as reactive as the least reactive compound, 4-methoxyphenyl glycidyl ether.

Table 3 summarizes dose-response results for the standard plate assays with those glycidyl ethers where such responses have not been previously reported and compares these data with those for the known mutagen, 1-naphthylmethyl glycidyl ether (Sugiura and Goto, 1983). Slopes for the increasing portion of these data, from doses where there was no evidence of toxicity (normal background lawns), were calculated using linear regression analysis. These slopes are reported in Table 3 together with their $r^{2}$ values.

All the compounds reverted both strains of Salmonella. 1-Naphthyl and 2-naphthyl glycidyl 


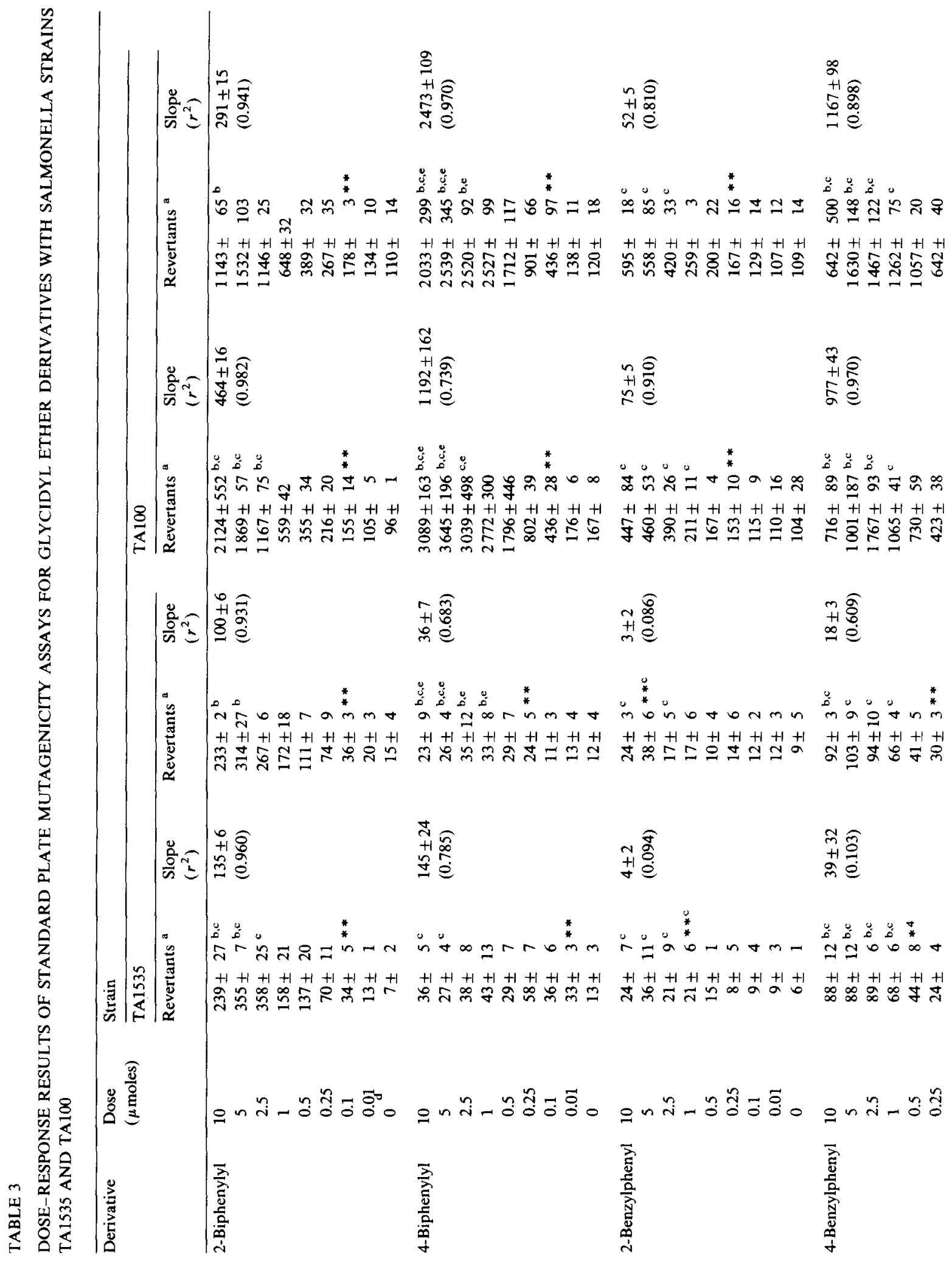




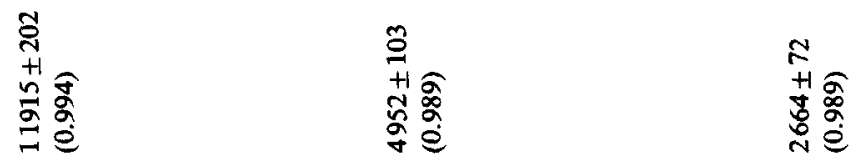

* $H+H+H+H+H+H+H+H+H+H+H+H+H+H+H+H$

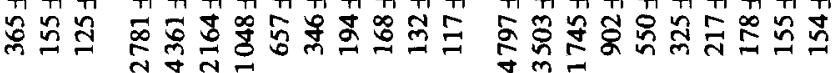

$\therefore+1+1+1+1+1+1+1$

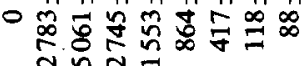
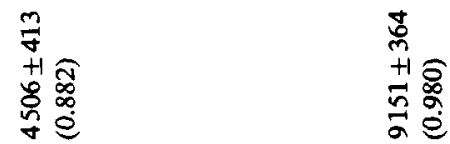

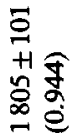

* $+H+H=H+H+H+H+H+H+H+1+H+H+H+H$

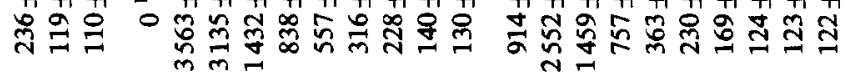

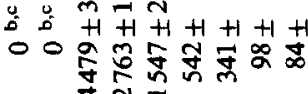

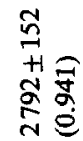
辛会

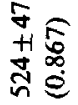

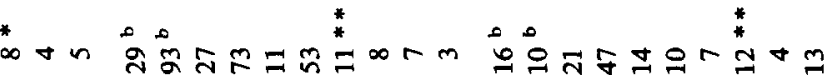
H H H H

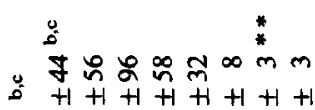

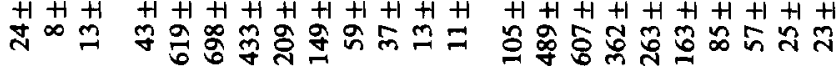

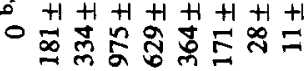

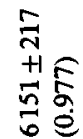

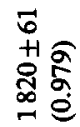
m

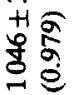

ー

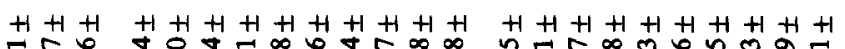

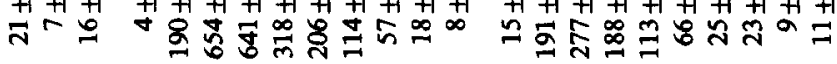

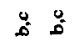

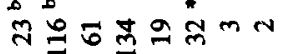
$\therefore+\vec{H}+\vec{H}+H+H$

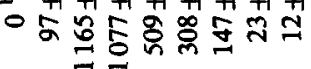

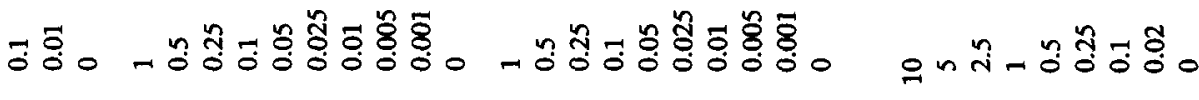
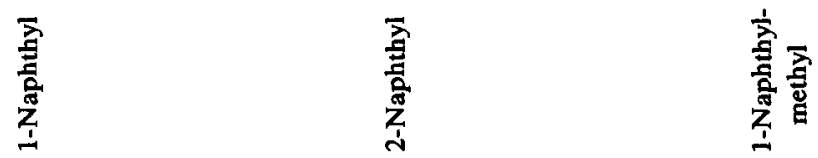
ether were the most mutagenic and also the most toxic compounds examined, while 2-benzylphenyl glycidyl ether was the weakest mutagen. Besides the expected increase in mutagenicity for strain TA100 because of the presence of its $R$ factor plasmid, some strain differences were detected. While the 4-benzylphenyl glycidyl ether was a stronger mutagen than 2-biphenylyl glycidyl ether in strain TA100, their order was reversed in strain TA1535.

Sugiura and Goto (1983) also observed strain differences in their glycidyl ether series. Their naphthylethyl, anthrylmethyl, and benzyl compounds were not mutagenic towards TA1535 but active in TA100. In addition, only 1-naphthylmethyl and 9-anthrylmethyl glycidyl ethers reverted strain TA98. In our previous study of glycidyl ethers (Neau et al., 1982), the phenyl ether and five $p$-substituted derivatives produced positive responses in both TA100 and TA1535, but the tert.-butyl compound was relatively inactive in the non-R factor strain. Canter et al. (1986) also demonstrated the inactivity of tert.-butylglycidyl ether in TA1535. Diminished activity was not related to toxicity in these investigations.

We have indicated (Djuric et al., 1986) that trichloropropylene oxide readily forms ringopened deoxyguanosine adducts which postulated to be excised by the repair system in TA1535, thereby accounting for the lowered potency in this Salmonella strain for this compound. However, while Sugiura and Goto (1983) noted that 7-substituted guanosine adducts of benzyl and 1-naphthylmethyl glycidyl ethers had the same decomposition rates in base, the parent glycidyl ethers differed in revertability with bacterial tester strains TA100 and TA1535. This does not support a hypothesis that varying rates of cleavage of the imidazole ring accounts for strain differences with the glycidyl ethers.

Fig. 1 summarizes the induced revertants in TA100 where the differences in mutagenicities were the most pronounced. Single-dose comparisons were also carried out with TA100 to examine these differences further and to extend the series for comparison with previous glycidyl ether studies (Neau et al., 1982; Sugiura and Goto, 1983) as well as to obtain mutagenicity data for correlation studies to the physical properties of these com-

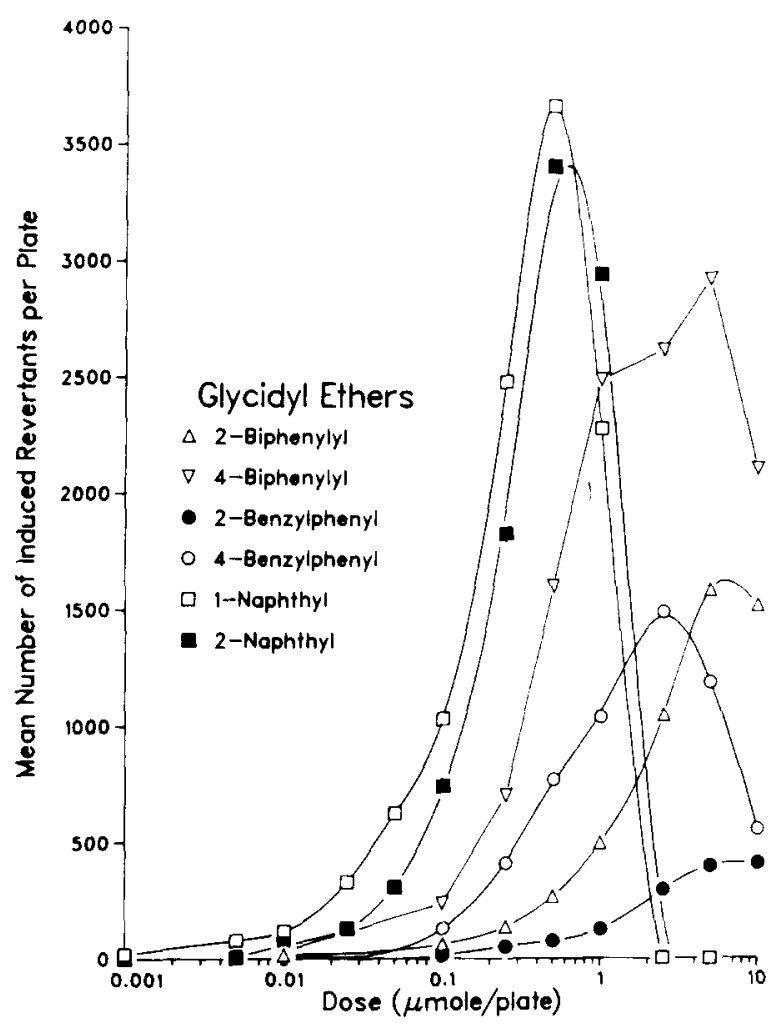

Fig. 1. Dose-response curves of induced revertants for Salmonella typhimurium TA100.

pounds. Single-dose comparisons were made on the same day using bacteria from the same overnight culture. This approach was used to minimize the problem of interexperimental variation in the Ames test (Cheli et al., 1980) and to control fluctuations due to differences in bacterial growth rate (Salmeen and Durisin, 1981). As noted in Fig. 1 and from our previous phenyl glycidyl ether dose-response curves (Neau et al., 1982), a concentration of $0.25 \mu \mathrm{mole} /$ plate provided the greatest variation between compounds at al level without apparent toxicity. Table 4 presents the results of the single-dose testing and their confirmation on a second day together with a ranking of the means of tests for both days.

All the results in Table 4 except those of 2-benzylphenyl glycidyl ether (rank 10) were significantly greater than the negative control $(p<$ 0.05) using Dunnett's many one $t$ test (Miller, 1981). The rank order of mutagenicity in the single-dose assays was consistent with the trends 
TABLE 4

SINGLE-DOSE COMPARISONS OF THE GLYCIDYL ETHERS AT $0.25 \mu \mathrm{mole} /$ plate USING SALMONELLA STRAIN TAI00 IN THE STANDARD PLATE ASSAY

\begin{tabular}{|c|c|c|}
\hline Derivative & Revertants $^{a}$ & Rank ${ }^{b}$ \\
\hline \multicolumn{3}{|l|}{ Control } \\
\hline DMSO & $\begin{array}{rr}88 \pm & 6 \\
112 \pm & 17\end{array}$ & \\
\hline \multicolumn{3}{|l|}{ Test compounds } \\
\hline 1-Naphthyl & $\begin{array}{l}3793 \pm 126 \\
2375 \pm 198\end{array}$ & $1 * * *$ \\
\hline 2-Naphthyl & $\begin{array}{l}1004 \pm 40 \\
1540 \pm 166\end{array}$ & $2 * * *$ \\
\hline 4-Nitrophenyl & $\begin{array}{l}666 \pm 51 \\
850 \pm 19\end{array}$ & 3 \\
\hline 4-Biphenylyl & $\begin{array}{l}725 \pm 75 \\
738 \pm 56\end{array}$ & $4^{*}$ \\
\hline 1-Naphthylmethyl & $\begin{array}{l}429 \pm 33 \\
660 \pm 77\end{array}$ & 5 \\
\hline 4-Benzylphenyl & $\begin{array}{l}514 \pm 67 \\
490 \pm 34\end{array}$ & $6 * *$ \\
\hline Phenyl & $\begin{array}{l}265 \pm 20 \\
305 \pm 18\end{array}$ & 7 \\
\hline 4-Methoxyphenyl & $\begin{array}{rr}238 \pm & 8 \\
310 \pm & 32\end{array}$ & 8 \\
\hline 2-Biphenylyl & $\begin{array}{l}211 \pm 6 \\
239 \pm 13\end{array}$ & $9 *$ \\
\hline 2-Benzylphenyl & $\begin{array}{r}138 \pm 11 \\
135 \pm 6\end{array}$ & 10 \\
\hline
\end{tabular}

a Average revertants \pm standard deviations for day $1(n=3)$ and day $2(n=3)$.

b Numbers are assigned and compounds listed in the order of the means of revertants for both days.

* Indicates means of revertants for both days are significantly greater than the means of revertants for the next higher numbered rank $(p<0.05)$ based on square roottransformed data using Tukey's pairwise comparisons (Neter and Wasserman, 1974).

** Same as above where $p<0.01$.

*** Same as above where $p<0.0001$.

observed from the dose-response curves (Fig. 1). The naphthyl glycidyl ethers placed in the top two positions, with 1-naphthyl significantly more mutagenic than 2-naphthyl ( $p<0.0001)$. The importance of the greater aromatic unsaturation and/or the resulting more planar structure of these naphthyl derivatives is also supported by the augmented mutagenicity of the 4-biphenylyl compound over its corresponding benzylphenyl derivative as well as its greater mutagenicity in comparison to the 2-biphenylyl and phenyl glycidyl ethers. Thus, those factors which decrease conjugation and planarity between the phenyl groups, such as the methylene bridge and restricted rotation due to ortho substitution, are consistent with a reduction in mutagenicity.

Both naphthyl glycidyl ethers were more mutagenic than the 1-naphthylmethyl derivative, where the epoxide group was further removed from the naphthyl group. This extends the work of Sugiura and Goto (1983) where naphthylmethyl glycidyl ethers were more mutagenic than their corresponding naphthylethyl ethers. This was also true for the effect of aromatic substitution, in general, in our aryl propylene and butylene oxide study where all butylene oxides were weaker mutagens than their propylene oxide counterparts (Rosman et al., 1987).

4-Nitrophenyl glycidyl ether ranked third, being more mutagenic than 1-naphthylmethyl glycidyl ether but comparable in activity to 4-biphenylyl glycidyl ether. As expected from our previous study (Neau et al., 1982), replacing the nitro with a methoxy substituent drastically reduced mutagenicity. 4-Methoxyphenyl glycidyl ether was equally mutagenic with 2-biphenylyl glycidyl ether and more potent than 2-benzylphenyl glycidyl ether. The unsubstituted phenyl glycidyl ether was also a relatively weak mutagen. Adding a benzyl group to this compound in the para position enhanced mutagenicity while in common with the biphenyl compounds substitution at the ortho position decreased the response.

The induced revertant values in Table 4 were analyzed to determine whether mutagenicity could be described in terms of chemical reactivity, molecular volume and hydrophobicity parameters which were important in structure-mutagenicity studies of styrene oxides (Tamura et al., 1982; Rosman et al., 1986). However, the correlations to nitrobenzyl pyridine reactivity, molecular volume and partition values for the present compounds (Table 2) were all poor $(r=0.255,-0.111$ and 0.121 , respectively) and a significant regression model could not be developed. Such structure-activity parameters appear to be less important in the present series than the degree of aromatic unsaturation with its resulting planarity and the distance of the aromaticity from the epoxide ring. These conclusions are consistent with Sugiura and 
Goto's (1983) study of aromatic glycidyl ethers and with our study of aryl propylene and butylene oxides (Rosman et al., 1987) indicating a frameshift contribution to the mutagenicity of the compounds with the more planar aromatic substituents. This is in agreement with the suggestion of Ames et al. (1973) that frameshift mutations require a flat aromatic moiety for intercalation and an electrophilic side chain for covalent binding to DNA. Direct support for a frameshift contribution to the mutagenicity of aryl oxides is given by the observation of Sugiura and Goto (1983) in their glycidyl ether series that the 1naphthylmethyl and 9-anthrylmethyl derivatives were mutagenic in the frameshift tester strain TA98. Work is in progress in our laboratory to define further the structural requirements for frameshift mutagenicity for aliphatic epoxides.

\section{Acknowledgements}

The authors wish to express their appreciation to Dr. Bruce Ames, University of California at Berkeley for supplying Salmonella tester strains TA100 and TA1535.

This investigation was supported by Grant R01 ES03345 from the National Institute of Environmental Health Sciences DHHS.

\section{References}

Ames, B.N., W.E. Durston, E. Yamasaki and F.D. Lee (1973) Carcinogens are mutagens: A simple test system combining liver homogenates for activation and bacteria detection, Proc. Natl. Acad. Sci. (U.S.A.), 70, 2281-2285.

Canter, D.A., E. Zeiger, S. Haworth, T. Lawlor, K. Mortelmans and W. Speck (1986) Comparative mutagenicity of aliphatic epoxides in Salmonella, Mutation Res., 172, 105-138.

Carlson, R.M., R.E. Carlson and H.L. Kopperman (1975) Determination of partition coefficients by liquid chromatography, J. Chromatogr., 107, 219-223.

Cheli, C., D. DeFrancesco, L.A. Petrullo, E.C. McCoy and H.S. Rosenkranz (1980) The Salmonella mutagenicity assay: reproducibility, Mutation Res., 74, 145-150.

Connor, T.H., J.B. Ward Jr., J. Meyne, T.G. Pullin and M.S. Legator (1980) The evaluation of the epoxide diluent, $n$ butylglycidyl ether, in a series of mutagenicity assays, Environ. Mutagen., 2, 521-530.

Djuric, Z., B.H. Hooberman, L. Rosman and J.E. Sinsheimer (1986) Reactivity of mutagenic propylene oxides with deoxynucleosides and DNA, Environ. Mutagen., 8, 369-383.
Fishbein, L. (1981) Carcinogenicity and mutagenicity of solvents, I. Glycidyl ethers, dioxane, nitroalkanes, dimethylformamide and allyl derivatives, Sci. Total Environ., 17. 97-110.

Frantz, S.W., and J.E. Sinsheimer (1981) Bacterial mutagenicity and toxicity of cycloaliphatic epoxides, Mutation Res.. 90, 67-78.

Frantz, S.W., E. van den Eeckhout, J.E. Sinsheimer, M. Yoshihara and M. Koreeda (1985) Mutagenicity in Salmonella assays of cyclohexane epoxide derivatives, Toxicol. Lett., 25, 265-271.

Frost, A.F., and M.S. Legator (1982) Unscheduled DNA synthesis induced in human lymphocytes by butyl glycidyl ethers, Mutation Res., 102, 193-200.

Greene, E.J., M.A. Friedman, J.A. Sherrod and A.J. Salerno (1979) In vitro mutagenicity and cell transformation screening of phenylglycidyl ether, Mutation Res., 67, 9-19.

Hammock, L.G., B.D. Hammock and J.E. Casida (1974) Detection and analysis of epoxides with 4-( $p$-nitrobenzyl)pyridine, Bull. Environ. Contam. Toxicol., 12, 759-764.

Hemminki, K., and K. Falck (1979) Correlation of mutagenicity and $4-(p$-nitrobenzyl)pyridine alkylation by epoxides, Toxicol. Lett., 4, 103-106.

Hemminki, K., K. Falck and H. Vainio (1980) Comparison of alkylation rates and mutagenicity of directly acting industrial and laboratory chemicals, Arch. Toxicol., 46, $277-285$.

Hopkins, J. (1984) Genotoxicity and carcinogenicity of glycidyl ethers, Food Chem. Toxicol., 22, 780-783.

Ivie, G.W., J.T. MacGregor and B.D. Hammock (1980) Mutagenicity of psoralen epoxides, Mutation Res., 79, 73-77.

Maron, D.M., and B.N. Ames (1983) Revised methods for the Salmonella mutagenicity test, Mutation Res., 113, 173-215.

Miller Jr., R.G. (1981) Simultaneous Statistical Inference, 2nd edn., Springer, New York, pp. 76-81.

Moriguchi, I., Y. Kanada and K. Komatsu (1976) Van der Waals volume and the related parameters for hydrophobicity in structure-activity studies, Chem. Pharm. Bull., 24, 1799-1806.

Neau, S.H., B.H. Hooberman, S.W. Frantz and J.E. Sinsheimer (1982) Substituent effects on the mutagenicity of phenyl glycidyl ethers in Salmonella typhimurium, Mutation Res., 93, 297-304.

Nelis, H.J.C.F., S.C. Airy and J.E. Sinsheimer (1982) Comparison of the alkylation of nicotinamide and 4-( $p$ nitrobenzyl)pyridine for the determination of aliphatic epoxides, Anal. Chem., 54, 213-216.

Neter, J., and W. Wasserman (1974) Applied Linear Statistical Models, Irwin, Homewood, IL, pp. 474-482, 507-508.

NIOSH (1978) Criteria for a recommended standard.... Occupational exposure to glycidyl ethers, U.S. Department of Health, Education and Welfare, Public Health Service, Center for Disease Control, National Institute for Occupational Safety and Health, Cincinnati, OH, $197 \mathrm{pp}$.

Nishioka, H., and H. Ohtani (1978) Mutagenicity of epoxide resins; constituents and commercial adhesives, in bacterial test systems, Mutation Res., 54, 247.

Rosman, L.B., V.G. Beylin, V. Gaddamidi, B.H. Hooberman 
and J.E. Sinsheimer (1986) Mutagenicity of para-substituted $\alpha$-methylstyrene oxide derivatives with Salmonella, Mutation Res., 171, 63-70.

Rosman, L.B., V. Gaddamidi and J.E. Sinsheimer (1987) Mutagenicity of aryl propylene and butylene oxides with Salmonella, Mutation Res., 189, 189-204.

Salmeen, I., and A.M. Durisin (1981) Some effects of bacteria population on quantitation of Ames Salmonella-histidine reversion mutagenesis assays, Mutation Res., 85, 109-118.

Seiler, J.P. (1984a) The mutagenicity of mono- and di-functional aromatic glycidyl compounds, Mutation Res., 135, $159-167$.

Seiler, J.P. (1984b) Uptake, metabolism and mutagenic activity of aromatic glycidyl compounds, Chem.-Biol. Interact., 51, 347-356.

Stein, H.P., N.A. Leidel and J.M. Lane (1979) NIOSH Current Intelligence Bulletin No. 29... Glycidyl ethers, Am. Ind. Hyg. Assoc. J., 40, A36-A51.

Sugiura, K., and M. Goto (1981) Mutagenicities of styrene oxide derivatives on bacterial test systems: relationship between mutagenic potencies and chemical reactivity, Chem.-Biol. Interact., 35, 71-91.

Sugiura, K., and M. Goto (1983) Mutagenicities of glycidyl ethers for Salmonella typhimurium: relationship between mutagenic potencies and chemical reactivity, Chem.-Biol. Interact., 45, 153-169.

Sugiura, K., T. Kimura and M. Goto (1978a) Mutagenicities of styrene oxide derivatives on Salmonella typhimurium (TA100), Relationship between mutagenic potencies and chemical reactivity, Mutation Res., 58, 159-165.

Sugiura, K., S. Yamanaka, S. Fukasawa and M. Goto (1978b)
The mutagenicity of substituted and unsubstituted styrene oxides in E. coli: relationship between mutagenic potencies and physico-chemical properties, Chemosphere, 9, 737-742.

Tamura, N., K. Takahashi, N. Shirai and Y. Kawazoe (1982) Studies on chemical carcinogens, XXI. Quantitative structure-mutagenicity relationship among substituted styrene oxides, Chem. Pharm. Bull., 30, 1393-1400.

Terrill, J.B., and K.P. Lee (1977) The inhalation toxicity of phenylglycidyl ether, I. 90-day inhalation study, Toxicol. Appl. Pharmacol., 42, 263-269.

Terrill, J.B., K.P. Lee, R. Culik and G.L. Kennedy Jr. (1982) The inhalation toxicity of phenylglycidyl ether: reproduction, mutagenic, teratogenic, and cytogenetic studies, Toxicol. Appl. Pharmacol., 64, 204-212.

Thompson, E.D., W.J. Coppinger, C.E. Piper, N. McCarroll, T.J. Oberly and D. Robinson (1981) Mutagenicity of alkyl glycidyl ethers in three short-term assays, Mutation Res., 90, 213-231.

Van Zyl, G., G.D. Zuidema, J.F. Zack Jr. and P.B, Kromann (1953) The course of ring opening of glycidyl ethers with nucleophilic reagents, J. Am. Chem. Soc., 75, 5002-5006.

Voogd, C.E., J.J. van der Stel and J.J.J.A.A. Jacobs (1981) The mutagenic action of aliphatic epoxides, Mutation Res., 89 , $269-282$.

Wade, D.R., S.C. Airy and J.E. Sinsheimer (1978) Mutagenicity of aliphatic epoxides, Mutation Res., 58, 217-223.

Wade, M.J., J.W. Moyer and C.H. Hine (1979) Mutagenic action of a series of epoxides, Mutation Res., 66, 367-371.

Whorton Jr., E.B., T.G. Pullin, A.F. Frost, A. Onofre, M.S. Legator and D.S. Folse (1983) Dominant lethal effects of n-butyl glycidyl ether in mice, Mutation Res., 124, 225-233. 